\title{
Efficacy of tank mixture glufosinate ammonium and indaziflam for weed control in oil palm
}

\author{
F. EKHATOR*, C.O. OKEKE, O.A. OGUNDIPE, B. AHMED \& C.E. IKUENOBE \\ (F.E, C.O.O, O.A.O \& C.E.I.: Nigerian Institute for oil Palm Research (NIFOR), Benin \\ City, Edo State; B.A.: Bayer Crop Science West-Central Africa SA, Côte d'Ivoire) \\ *Corresponding author's email: kenekh2003@yahoo.co.uk
}

\begin{abstract}
The apprehension among oil palm farmers on the toxicity of glyphosate necessitated the need for an alternative herbicide for weed control in oil palm. Thus, a study was conducted at the Nigerian Institute for Oil Palm Research (NIFOR) to determine the efficacy of tank mixture of glufosinate ammonium (Basta) + indaziflam (Alion) for weed control in oil palm. The treatments consisted of glyphosate at $1.5 \mathrm{~kg}$ a.i ha ${ }^{-1}$, glyphosate + diuron at $1.5+2.0 \mathrm{~kg}$ a.i. ha ${ }^{-1}$, glufosinate ammonium at $0.4 \mathrm{~kg}$ a.i. ha ${ }^{-1}$, glufosinate ammonium at $0.5 \mathrm{~kg}$ a.i. ha ${ }^{-1}$, tank mixture of glufosinate ammonium + indaziflam at $0.4+0.04 \mathrm{~kg}$ a.i. $\mathrm{ha}^{-1}$, tank mixture of glufosinate ammonium + indaziflam at $0.5+0.04 \mathrm{~kg}$ a.i. ha ${ }^{-1}$ and weedy control. The results showed that tank mixture of glyphosate + diuron at $1.5+2 \mathrm{~kg}$ a.i ha ${ }^{-1}$, glufosinate ammonium + indaziflam at $0.4+0.04$ $\mathrm{kg}$ a.i. ha ${ }^{-1}$ and glufosinate ammonium + indaziflam at $0.5+0.04$ had the best weed control efficiency of $78.5 \%, 78.6 \%$ and $78.3 \%$ respectively up to 20 weeks. The study concluded that tank mixtures of glufosinate ammonium + indaziflam were as good as glyphosate + diuron for weed control in oil palm.
\end{abstract}

Keywords: oil palm; weed; efficacy; herbicide; weed flora

Original scientific paper. Received 14 Jun 2020; revised 30 Apr 2021

\section{Introduction}

Manual weeding has constituted a serious weed control problem in oil palm because of the required labour for the frequent slashing of the luxuriant weed growth within the wide inter-row spacing in oil palm production. The scarcity of labour and the huge cost involved in weeding the inter-rows and circles around the palms has made some small-scale oil palm farmers abandon their plantations. Planting cover crops to suppress weeds could have been better; however, the high cost of procuring and establishment of cover crops is beyond the reach of most small-scale farmers (Ekhator et al., 2020).

Therefore, chemical weed control which has been the alternate practice among small-scale farmers and large-scale oil palm growers becomes imperative. In effect, this has reduced the dependence on labour for hand weeding which often delays operations in times of scarcity (Hornus, 1990). Manual weeding which is often practiced among smallscale oil palm farmers can be more expensive than chemical weeding (Hamel, 1986). Thus, chemical weeding is considered a suitable

Ghana Jnl Agric. Sci. 56 (1), 87 - 103

GJAS is an Open Access Journal and distributed under the terms of the Creative Commons (CC) License [CC BY 4.0] 
alternative for weed management especially in large-scale oil palm plantations (Ekhator et al., 2018a).

Glyphosate provides control of broad spectrum of weeds in oil palm fields (Ikuenobe, 1992). Tank mixture of glyphosate + metsulforon has been shown to be effective for annual and perennial weed control in the oil palm (Ekhator et al., 2018a). Other herbicides, such as Folar (glyphosate + terbuthylazine), glyphosate + indaziflam, Velpar k4 (Hexazinone), triclopyr, and triclopyr + asulam have also been found suitable for weed control in oil palm (Ekhator et al., 2020; NIFOR, 2003; Boum \& Hornus, 1987; Queneez \& Dufor, 1982a).

The apprehension among farmers on the toxicity of glyphosate for weed control in oil palm especially at the juvenile stage of field establishment has necessitated the need for a friendly herbicide for oil palm production.

Glufosinate ammonium (Basta) is a partial systemic post-emergence herbicide used in the control of both annual and perennial weeds in plantation crops (Akobundu, 1987); while indaziflam (Alion) is a systemic herbicide for selective pre-emergence control against broadleaves weeds and some grasses in plantation crops (Ekhator et al., 2020). The long soil residual activity of indaziflam could provide long-term weed control when in mixture with other post-emergence herbicides (Ekhatoret al., 2020). Herbicide could reduce application cost and herbicide resistance of weeds (Diggle et al., 2003; Lich et al., 1997). Tank mixtures of herbicides broaden the spectrum of weed species control and provide good control at considerably lower dosages than dosages utilized in single applications (Ekhator et al., 2018a). Glufosinate ammonium (Basta) and indaziflam (Alion) are newly formulated products of Bayer Crop Science West and
Central Africa and were sponsored in NIFOR for evaluation on weed control in oil palm.

The objective of this study was to evaluate the effect of glufosinate ammonium and indaziflam along with glyphosate and diuron commonly used for weed control in oil palm.

\section{Materials and Methods}

The experiment with seven treatments was laid out in a randomized complete block design in three replicates in field 30 at the Nigerian Institute for Oil palm Research (NIFOR), Benin City, Nigeria. The total plot and experimental unit size adopted were $16,200 \mathrm{~m}^{2}(406 \mathrm{~m} \mathrm{x} 45$ $\mathrm{m})$ and $144 \mathrm{~m}^{2}(36 \mathrm{~m} \mathrm{x} 4 \mathrm{~m})$ respectively. The palms in field 30 were planted in May, 2015 and were one year and three months old at the commencement of the trial in July, 2016. The palms were planted in a standard spacing of 9 $\mathrm{m} \times 9 \mathrm{~m}$ in triangular (NIFOR, 2003). Four meter-wide strips of palm rows were applied with the appropriate herbicide treatments. The treatments consisted of glyphosate at $1.5 \mathrm{~kg}$ a.i $\mathrm{ha}^{-1}$ (as reference single herbicide), glyphosate + diuron at $1.5+2.0 \mathrm{~kg}$ a.i. $\mathrm{ha}^{-1}$ (as reference tank-mixed herbicide), glufosinate ammonium at $0.4 \mathrm{~kg}$ a.i. $\mathrm{ha}^{-1}$, glufosinate ammonium at $0.5 \mathrm{~kg}$ a.i. ha ${ }^{-1}$, tank mixture of glufosinate ammonium + indaziflam at $0.4+0.04 \mathrm{~kg}$ a.i. $\mathrm{ha}^{-1}$, tank mixture of glufosinate ammonium + indaziflam at $0.5+0.04 \mathrm{~kg}$ a.i. ha ${ }^{-1}$ and weedy plot (non-treated plot reference). These were applied post-emergence to actively re-growing weeds slashed four weeks prior to herbicide application. Herbicides were applied using a manually mounted 15 liters knapsack sprayer fitted with a hand-held operated nozzle and calibrated to deliver a spray volume of 240 liters per hectare. The herbicides were applied in the morning during warm temperatures and 
high humidity. Data recorded monthly were predominant weed flora, visual assessment of weed control, biomass of weed growth, weed control efficiency, and weed coverage and herbicide toxicity. Weed control efficacy in the treated plots was interpreted according to the scale of the European Weeds Research Council (EWRC) (Marnotte \& Tehia, 1992; Mathieu \& Marnotte, 2000; Auskalnis, 2003; Ekhator et al., 2018a). European Weed Research Society Scale (EWRS) was used to interpret herbicide toxicity. Results interpreted were reference to the two scales. The tables are presented in appendixes $i$ and ii.

\section{Weed dry (biomass) weight}

The weed shoot falling within the frames of the quadrat of size $1 \mathrm{~m} \times 1 \mathrm{~m}$ were harvested from the ground level after throwing the quadrat randomly within each experimental plot four times. Then, the mean weed dry weight of the quadrats was recorded after oven-dried to a constant weight at $80^{\circ} \mathrm{C}$ for 72 hours.

\section{Visual weed control rating}

Visual weed control rating was taken by using the weedy plot as reference. Then visual assessment of the percentage reduction of weeds in the treatment plots was compared to the weedy plot.

\section{Weed control efficiency}

Weed control efficiency was calculated as per the procedure

$W C E \%=\frac{W D_{C}-W D_{T}}{W D_{C}} \times 100$

Where WCE Represents weed control efficiency (percent)

$W D_{C}$ Represents weed biomass $\left(\mathrm{kg} \cdot \mathrm{m}^{-2}\right)$ in control (weedy) plot
$W D_{T}$ Represents weed biomass $\left(\mathrm{kg} \cdot \mathrm{m}^{-2}\right)$ in treated plot (Ofosu-Budu et al., 2014, Ekhator et al., 2018a). Weed coverage: Weed coverage was assessed by visual estimation of the percentage coverage of the emerged weeds in the treated plot within the $1 \mathrm{~m} \times 1 \mathrm{~m}$ quadrat against the weedy plot as explained by EWRC for herbicide evaluation (Ekhator et al., 2018a).

\section{Herbicide toxicity}

Plant toxicity due to herbicide was assessed by comparison of the state of palm tree fronds in the treatment plots with area without herbicide treatment at the slashed inter-rows borders lines. The toxicity rating was assessed using EWRS -scale for visual rating of herbicide toxicity

\section{Statistical Analysis}

The data on weeds were statistically analyzed using the analysis of variance in Gen Stat Version 8.1 (2005). Where significant differences existed, the critical difference was constructed at a five percent probability level for guidance. However, interpretation of results was largely based on EWRC scale for herbicide evaluation and EWRS - scale for toxicity-

\section{Weed flora}

\section{Results and Discussion}

A total of forty-eight initial weed species were recorded at the commencement of the study. Of these, thirty were perennial and eighteen annual. Twenty-five families were dicots species while three families were monocots species. Although dicots dominated the field, the three families of the monocots were Poaceae, Commelinaceae and Cyperaceae (Table 1). 
Weed control rating on individual weed species Glyphosate applied at $1.5 \mathrm{~kg}$ a.i. ha ${ }^{-1}$, glyphosate + diuron at $1.5+2 \mathrm{~kg}$ a.i. ha ${ }^{-1}$, glufosinate ammonium at $0.4 \mathrm{~kg}$ a.i. ha ${ }^{-1}$, glufosinate ammonium at $0.5 \mathrm{~kg}$ a.i. ha $\mathrm{h}^{-1}$ controlled $70.83 \%$ of the weed species, while $29.2 \%$ of the weed species were either fairly or poorly controlled. Tank mixture of glufosinate ammonium + indaziflam at $0.4+0.04 \mathrm{~kg}$ a.i. ha ${ }^{-1}$, glufosinate ammonium+ indaziflam at $0.4+0.05 \mathrm{~kg}$ a.i. $\mathrm{ha}^{-1}$ controlled $75 \%$ of individual weed species while $25 \%$ of the individual weed species present were either fairly or poorly controlled (Table 2). Consequently, $25 \%$ of both dicot. and monocot. weed species recorded were not controlled by the herbicide's treatment (Tables $1 \& 2)$.

\section{Difficult to control weeds}

Fourteen weed species among the forty-eight weeds identified to be poorly or either not control by all the herbicide treatments were Acanthus montanus, Alchornea cordifolia, Alchornea laxiflora, Brachiara deflexa, Cnestis ferruginea, Combretum racemosum, Commelina diffusa, Commelina Benghalensis, Euphorbia Heterophylla, Peperomia pellucid, Rauwolfia vomitora, Synelisia scabrida and Talinium triangulare (Table 2).

\section{Emerged weed species}

Following herbicide treatments at the experimental plots, glyphosate applied at 1.5 $\mathrm{kg}$ a.i. $\mathrm{ha}^{-1}$ had 28 emerged weed species $/ \mathrm{m}^{2}$ with corresponding density of $44 / \mathrm{m}^{2}$. Tank mixture of glyphosate + diuron at $1.5+2.0$ $\mathrm{kg}$ a.i. $\mathrm{ha}^{-1}$ had 24 emerged weed species $/ \mathrm{m}^{2}$ with density of $30 / \mathrm{m}^{2}$. The plot treated with glufosinate ammonium at $0.4 \mathrm{~kg}$ a.i. $\mathrm{ha}^{-1}$ and glufosinate ammonium $0.5 \mathrm{~kg}$ a.i. $\mathrm{ha}^{-1}$ had number of emerged weed species of 23 and $23 / \mathrm{m}^{2}$ respectively and density of 64 and 62
$/ \mathrm{m}^{2}$ respectively. Furthermore, plots treated with tank mixture of glufosinate ammonium + indaziflam at $0.4+0.04 \mathrm{~kg}$ a.i ha ${ }^{-1}$ and at $0.5+$ $0.04 \mathrm{~kg}$ a.i. $\mathrm{ha}^{-1}$ had emerged weed species of 25 and $27 / \mathrm{m}^{2}$ respectively and weed density of 30 and $28 / \mathrm{m}^{2}$ respectively (Table 3 ). The weedy plot recorded the highest emerged weed species of $40 / \mathrm{m}^{2}$ and density of $175 / \mathrm{m}^{2}$ (Table 3).

\section{Visual weed control rating}

Herbicide treatments of glyphosate at $1.5 \mathrm{~kg}$ a.i $\mathrm{ha}^{-1}$, glyphosate + diuron at $1.5+2.0 \mathrm{~kg}$ a.i. $\mathrm{ha}^{-1}$, glufosinate ammonium at $0.4 \mathrm{~kg}$ a.i. ha ${ }^{-1}$, glufosinate ammonium at $0.5 \mathrm{~kg}$ a.i. ha ${ }^{-1}$, tank mixture of glufosinate ammonium + indaziflam at $0.4+0.04 \mathrm{~kg}$ a.i. ha ${ }^{-1}$, tank mixture of glufosinate ammonium + indaziflam at $0.5+$ $0.04 \mathrm{~kg}$ a.i. $\mathrm{ha}^{-1}$ were significantly different in visual weed control rating and sustained weed control of over $72 \%$ by eight weeks after treatment application. However, treatments of glyphosate + diuron at $1.5+2.0 \mathrm{~kg}$ a.i. ha${ }^{1}$, tank mixture of glufosinate ammonium + indaziflam at $0.4+0.04 \mathrm{~kg} \mathrm{a.i.} \mathrm{ha}^{-1}$, and tank mixture of glufosinate ammonium + indaziflam at $0.5+0.04 \mathrm{~kg}$ a.i. ha ${ }^{-1}$ were significantly similar in activities up to 12 weeks and had weed incidence reduction of $89 \%, 91 \%$ and $91 \%$ respectively. At 16 weeks, weed incidence reduction in all treatments was also significantly dissimilar; and only the treatments with tank mixture glufosinate ammonium + indaziflam at $0.4+0.04 \mathrm{~kg}$ a.i. $\mathrm{ha}^{-1}$, and glufosinate ammonium + indaziflam at $0.5+0.04 \mathrm{~kg}$ a.i. ha $^{-1}$ had similar activities with over $74 \%$ weed incidence reduction. At 20 and 24 weeks poor weed incidence reduction was sustained in all the treatments. Glyphosate + diuron at 1.5 $+2.0 \mathrm{~kg}$ a.i. ha ${ }^{-1}$, tank mixture of glufosinate ammonium + indaziflam at $0.4+0.04 \mathrm{~kg}$ a.i. ha${ }^{1}$, and tank mixture of glufosinate ammonium + 
indaziflam at $0.5+0.04 \mathrm{~kg}$ a.i. ha ${ }^{-1}$ had similar weed incidence reduction of $52.3 \%, 53.7 \%$ and $53.3 \%$ at 20 weeks; and $32.7 \%, 32.3 \%$ and $32.3 \%$ at 24 respectively (Table 4 ).

\section{Biomass weed reduction}

Biomass of weed reduction was significantly different up to 24 weeks in all herbicide treatments However, glyphosate at $1.5 \mathrm{~kg}$ a.i. $\mathrm{ha}^{-1}$ reduced weed biomass over control to 163 $\mathrm{g} \cdot \mathrm{m}^{-2}$ and $241 \mathrm{~g} \cdot \mathrm{m}^{-2}$ at four weeks and 12 weeks respectively. Tank mixtures of glyphosate at $1.5 \mathrm{~kg}$ a.i. ha- ${ }^{-1}+$ diuron at $2 \mathrm{~kg}$ a.i. ha ${ }^{-1}$ reduces weed biomass to $162 \mathrm{~g} \cdot \mathrm{m}^{-2}$ and $232 \mathrm{~g} \cdot \mathrm{m}^{-2}$ at four weeks and 16 weeks respectively (Table 7). Glufosinate ammonium at $0.4 \mathrm{~kg}$ a.i. ha- ${ }^{1}$ and at $0.5 \mathrm{~kg}$ a.i. ha- ${ }^{1}$ reduced weed biomass to $275 \mathrm{~g} \cdot \mathrm{m}^{-2}$ and $263 \mathrm{~g} \cdot \mathrm{m}^{-2}$ respectively at four weeks; then to $332 \mathrm{~g} \cdot \mathrm{m}^{-2}$ and $206 \mathrm{~g} \cdot \mathrm{m}^{-2}$ respectively at eight weeks. Furthermore, tank mixture of glufosinate ammonium + indaziflam at $0.4 \mathrm{~kg}$ a.i. $\mathrm{ha}^{-1}+0.04 \mathrm{~kg}$ a.i. ha ${ }^{-1}$ or tank mixture of glufosinate ammonium + indaziflam at $0.5 \mathrm{~kg}$ a.i. ha $\mathrm{h}^{-1}+0.04 \mathrm{~kg}$ a.i. ha ${ }^{-1}$ had better weed biomass reduction of $221.7 \mathrm{~g} \cdot \mathrm{m}^{-2}$ and 225 $\mathrm{g} \cdot \mathrm{m}^{-2}$ respectively at 16 weeks after treatment (Table 5).

\section{Weed control efficiency}

Glyphosate at $1.5 \mathrm{~kg}$ a.i. ha ${ }^{-1}$ had moderate weed control efficiency of $87 \%$ and $67.2 \%$ respectively at four weeks and 16 weeks after treatment. Then, tank mixture of glyphosate + diuron at $1.5 \mathrm{~kg}$ a.i. ha ${ }^{-1}+2 \mathrm{~kg}$ a.i. ha ${ }^{-1}$ had moderate and acceptably weed control efficiency with value of $87 \%$ and $78.5 \%$ respectively at four weeks and 20 weeks after treatment (Table 6). In effect, glufosinate ammonium at $0.4 \mathrm{~kg}$ a.i. $\mathrm{ha}^{-1}$ and at $0.5 \mathrm{~kg}$ a.i. $\mathrm{ha}^{-1}$ had short duration of efficacy with weed control efficiency value of $69.4 \%$ and $72 \%$ respectively at 12 weeks after treatment (Table
8). Consequently, tank mixture of glufosinate ammonium + indaziflam at $0.4 \mathrm{~kg}$ a. i. $\mathrm{ha}^{-1}+$ $0.04 \mathrm{~kg}$ a.i. ha ${ }^{-1}$ was more efficacious with value of $87 \%$ and $78.6 \%$ respectively at four weeks and 20 weeks after treatment. Furthermore, tank mixture of glufosinate ammonium + indaziflam at $0.5 \mathrm{~kg}$ a.i. $\mathrm{ha}^{-1}+0.04 \mathrm{~kg}$ a.i. $\mathrm{ha}^{-1}$ was very efficient and acceptably efficacious with value of $87 \%$ and $78.3 \%$ at four weeks and 20 weeks after treatment (Table 6).

\section{Weed coverage}

Among the seven treatments, only tank mixture of glyphosate + diuron at $1.5 \mathrm{~kg}$ a.i. $\mathrm{ha}^{-1}+2 \mathrm{~kg}$ a.i. ha ${ }^{-1}$, tank mixture of glufosinate ammonium + indaziflam at $0.4 \mathrm{~kg}$ a.i. $\mathrm{ha}^{-1}+0.04 \mathrm{~kg}$ a.i. $\mathrm{ha}^{-1}$ and tank mixture of glufosinate ammonium + indaziflam at $0.5 \mathrm{~kg}$ a.i. ha ${ }^{-1}+0.04 \mathrm{~kg}$ a.i. ha ${ }^{-1}$ had acceptable weed coverage value of $14.7 \%$, $13.3 \%$ and $13 \%$ respectively at 12 weeks after treatment (Table 7). However, glyphosate at $1.5 \mathrm{~kg}$ a.i. ha ${ }^{-1}$, glufosinate ammonium at 0.4 $\mathrm{kg}$ a.i. $\mathrm{ha}^{-1}$ and glufosinate ammonium at $0.5 \mathrm{~kg}$ a.i. ha ${ }^{-1}$ had moderately to poor weed coverage of $37.7 \%, 45 \%$ and $44 \%$ respectively at 12 weeks after treatment (Table 7). Glufosinate ammonium alone had moderate weed coverage only up to eight weeks after treatment (Table 7).

\section{Herbicide toxicity}

The effect of glyphosate at $1.5 \mathrm{~kg}$ a.i. ha ${ }^{-1}$ and glyphosate + diuron at $1.5+2 \mathrm{~kg}$ a.i. $\mathrm{ha}^{-1}$ had toxicity class of $2 \& 3$ with only slight, but clear symptom of yellowing at the palm fronds tip (Table 8). The palm fronds only recovered from the herbicide's symptoms after eight weeks after herbicide application. Palms in plots treated with glufosinate ammonium at 0.4 $\mathrm{kg}$ a.i. ha ${ }^{-1}$, glufosinate ammonium at $0.5 \mathrm{~kg}$ a.i. $\mathrm{ha}^{-1}$, tank mixture of glufosinate ammonium + indaziflam at $0.4+0.04 \mathrm{~kg}$ a.i. $\mathrm{ha}^{-1}$, tank 
mixture of glufosinate ammonium + indaziflam at $0.5+0.04 \mathrm{~kg}$ a.i. ha ${ }^{-1}$ had toxicity class 1 no symptoms of herbicide toxicity on the palm fronds (Table 8).

\section{Weed flora}

The high population of perennial weeds at the experimental site could be due to the fact that in oil palm cropping systems the soil is hardly tilled or turn over and this practice could allow for the growth of perennial weeds. The high population of dicots $(83.33 \%)$ over monocots (16.7\%) could be due to cultural practices/ cropping systems, cropping history, prevalent high annual rainfall of $1800 \mathrm{~mm}$, fertile soil with mean $\mathrm{pH}$ of 5.2 and fluctuations in temperatures of between $23.5^{\circ} \mathrm{C}$ to $31.7^{\circ} \mathrm{C}$ within the seasons (wet and dry season) in the area. Sit et al. (2007) and Traoré et al. (2010) had previously reported dominance of dicots in oil palm field in India and Côte d' Ivoire respectively.

Weed control rating on individual weed species The high rate of control of various weed species could be due to the broad spectrum of activities of the herbicide treatments. Glyphosate, glufosinate ammonium, diuron, indaziflam had been found previously to control broad spectrum of weeds including broad leaves and grasses in crops (Akobundu, 1987). This broad spectrum of activity of the herbicides will be very apt for the oil palm farmers because only few weeds will require farmer's intervention during the period of the herbicide's activities.

\section{Difficult to control weeds}

The weeds such as Acanthus montanus, Alchornea cordifolia, Alchornea laxiflora, Brachiara deflexa, Cnestis ferruginea, Combretum racemosum, Commelina diffusa,
Commelina Benghalensis, Euphorbia Heterophylla, Peperomia pellucid, Rauwolfia vomitora, Synelisia scabrida and Talinium triangulare that were poorly controlled by the herbicide treatments could be attributed to both the morphological and physiological state of the weeds and this needs further investigation to enable the selection of appropriate herbicide in other to relief oil palm farmers of the menace posed by these weeds.

\section{Emerged weed species}

The higher density of emerged weeds from the treatment of glufosinate ammonium compared to the treatments of glyphosate + diuron or glufosinate ammonium + indaziflam could be attributed to the non residual activity of glufosinate ammonium, while diuronis is known to have soil residual activity (Akobundu, 1987) The emerged weed density from the treatment of glyphosate was lower than the density of emerged weeds from the glufosinate plot probably because of the fact that glyphosate could have some level soil residual activity. While the low density of emerged weed from treatments of glufosinate ammonium + indaziflam could be due to the soil residual activity of indaziflam in the tank mixtures.

\section{Visual weed control rating}

The effectiveness of tank mixture of glufosinate ammonium + indaziflam for a long period of weed control could have resulted from the synergies of activities of the herbicides in mixture. Glufosinate ammonium controls both annual and perennial weeds, while indaziflam has a pre-emergence control against broadleaves weeds and some grasses. Tank mixtures of herbicide for weed control have been reported previously by Akobundu (1987) to either be great- 
er (synergistic) or reduce (antagonistic) in plant response. Synergistic responses resulting from the application of different herbicides in mixtures had previously been observed in oil palm (Ekhator et al., 2018a; Ekhator et al., 2020). This long synergy of activities of the herbicides will benefit oil palm farmers because oil palm farmers will have to concentrate on other agronomic activities such as timely harvesting of ripe fruit and application of fertilizers.

\section{Weed biomass}

The similarity in low weed weight recorded over longer duration between tank mixture of glyphosate + diuron and tank mixture of glufosinate ammonium + indaziflam is an indication that tank mixture of glufosinate ammonium + indaziflam could serve as alternative choice herbicide for weed control in oil palm. The longer weed-free period observed will enable oil palm farmers to concentrate more on other cultural practices than controlling weeds. The low weed weight recorded could have indicated minimal competition of weeds with the palms. Significant reduction in weed weight has been observed previously as the most important parameter in assessing the competitiveness for crop growth and productivity because considerable reduction in weed weight implies less competition from weed (Ramalingram et al., 2013).

\section{Weed control efficiency}

The moderate effectiveness of tank mixture of glyphosate + diuron and tank mixture of glufosinate ammonium + indaziflam for a longer period could be attributed to the preemergence activity of diuron and indaziflam in the herbicides mixtures which could have suppressed further weed seed emergence. Ekhator et al. (2018a) had previously reported a similar result with tank mixture of glyphosate + metsulfuron for weed control in oil palm. The similarity in efficacy of the tank mixed herbicides over a longer period showed that tank mixture of glufosinate ammonium + indaziflam could serve as an alternative choice herbicide for long period of weed control in oil palm.

\section{Weed coverage}

The moderate weed coverage observed with glyphosate +diuron in mixture and tank mixture of glufosinate ammonium + indaziflam could have resulted from the high activities of the herbicides in mixtures. These effects could be partly due to the residual effect of the pre-emergence herbicides in the mixture. This result could have indicated minimal competition of weed with the crop. Ekhator et al. (2018a) had previously reported similar results with glyphosate + metsulfuron for weed control in juvenile oil palm.

\section{Herbicide toxicity}

The slight symptom observed in oil palm frond with glyphosate + diuron is an indication that oil palm farmers need to be careful of glyphosate usage and most especially its abuse. The early recovery observed with the palms frond is an indication that minimal risk will be borne by the farmers in using glyphosate or glyphosate + diuron at the recommended rate. The healthy palms observed with glufosinate ammonium or glufosinate ammonium + indziflan are indicative of the suitability of these herbicides for weed control in oil palm. 


\section{Conclusion}

The result concluded that tank mixture of glyphosate + diuron at $1.5+2.0 \mathrm{~kg}$ a.i. $\mathrm{ha}^{-}$ 1, tank mixture of glufosinate ammonium + indaziflam at $0.4+0.04 \mathrm{~kg}$ a.i. $\mathrm{ha}^{-1}$ and tank mixture of glufosinate ammonium + indaziflam at $0.5+0.04 \mathrm{~kg}$ a.i. ha $^{-1}$ were very effective in broad spectrum of weed control in oil palm. Treatments with tank mixture of glyphosate + diuron at $1.5+2.0 \mathrm{~kg}$ a.i. $\mathrm{ha}^{-1}$, glufosinate ammonium + indaziflam at $0.4+0.04 \mathrm{~kg}$ a.i. $\mathrm{ha}^{-1}$, and glufosinate ammonium + indaziflam at $0.5+0.04 \mathrm{~kg}$ a.i. ha ${ }^{-1}$ sustained weed control of over $74 \%$ for a longer period of 16 weeks.

\section{Recommendation}

This study recommends tank mixture of glufosinate ammonium + indaziflam at $0.4 \mathrm{~kg}$ a.i. ha ${ }^{-1}$ $+0.04 \mathrm{~kg}$ a.i. $\mathrm{ha}^{-1}$ serves as alternative choice herbicide to glyphosate +diuron for weed control in oil palm.

\section{Acknowledgement}

The authors are grateful to Bayer Crop Science West-Central Africa S.A for providing grant and herbicides materials for this research work. Further thanks go to our Executive Director R\&D/ CEO of NIFOR for the support during this research work.

The authors are also grateful to colleagues in the Agronomy Division, NIFOR for their support in the execution of this research. This paper is published with the permission of the Executive Director, NIFOR. Above all, we appreciate God almighty for his mercy and kindness during the period.

\section{REFERENCES}

Akobundu, I.O. (1987) Weed science in the tropics. Principles and practices. Wiley, Chichester, UK. p. 522.

Auskalnis, A. (2003) Experience with Plant Protection on line for weed control in Lithuania. In the Proceedings of the 2003 Crop Protection Conference for the Baltic Sea Region, 166 - 175.

Boum, M. \& Hornus, P. (1987) Emploi du triclopyr pour I'eradication des recrusarbustifs en plantation de palmier a huile Oleag 42 (11), 403 -408 .

Diggle, A. J., Neve, P. B. \& Smith, F. P. (2003) Herbicides used in combination can reduce the probability of herbicide resistance in finite weed population. Weed Research 43,371 382.

Ekhator, F., Ola, O.T. \& Ikuenobe, C.E. (2018a). Effectiveness of tank mixture of glyphosate plus Metsulfuron for weed control in a juvenile oil palm in Nigeria. International Journal of Agronomy and Agricultural Research (IJAAR) 13 (1), 29 - 38. ISSN: 2223-7054(Print) 2225-3610(Online).

Ekhator, F., Okeke, C. O., Ogundipe, O. A., Ahmed. B \& Ikuenobe, C.E. (2020) Evaluation of new formulation of Indaziflam for Weed Control in Oil Palm in Nigeria. Nigerian Journal of Weed Science 33. In press

Faccini, D. \& Puricelli, E. (2007) Efficacy of herbicide dose and growth stage on weeds present in fallow ground. AGRISCIENTIA 24 (1), 29 -35 .

GenStat Release (2005) Version 8.1. Lawes Agricultural Trust (Rothamsted Experimental Station) Registered to: TEAM TBE 2005-08-13. 
Hamel, P. (1986) Une technique de lute chhimiquecontre Eupatorium odoratum(L.) Pour les replantation de palmieràhuileOléag 45 (3),112 -118 .

Hornus, P. H. (1990) Adaptation des techniques TBV a goutteletes controlees pour les traitementsdes ronds de palmiersadultes. Oleag 38 (5).

Ikuenobe, C.E. (1992) Field evaluation of glufosinate ammonium and glyphosate trimesium against Siam weed (Chromolaena odorata L.). Test of Agrochenicals and Cultivars 13, $44-45$.

Marnotte, P. \& Tehia, K. E. (1992) Bilan de triosannéesd'essaisd'efficacited'herbicides de prélevée pour la culture de mais en zone centre de Côte d'Ivoire. In. Actes de la 15ème conférence.Sur la biologie des mauvaisesherbes. Versailles (France), COLUMA. 1231 - 1238.

Mathieu, B. \& Marnotte, P. (2000) L'enherbement des sols à Muskuwari au Nord-Cameroun.In: Actes du 11ème Collaboration Internationale. sur la biologie des mauvaisesherbes. Dijon (France), COLUMA, $151-158$.

NIFOR.(2003) A manual on oil palm production.(7th edition.) Mesega, printers and publishers, Benin City, Nigeria. $1-5$.
Ofosu-Budu, K. G., Zutah, V. T., Avaala, S. A. \& Baafi, J. (2014) Evaluation of metsulfuron-methy and combinations in controlling weeds in Juvenile oil palm plantation. International Journal of Agronomy and Agricultural Research (IJAAR) 4 (4), 9 - 19.

Quencez, P. \& Dufour, F. (1982b) La lute chimiquecontre les mauvaisesherbes en palmeraic: La prèparation des solutions, I' organization des chantierset la pratique du traitement. Oleag $\mathbf{3 7}$ (4), $169-173$.

Ramalingram, S. P., Chinnagounder, C., Perrunal, M. \& Palanisamy, M.A. (2013) Evaluation of new formulation of oxyfluorten $(23.5 \%)$ for weed control efficacy and bulb yield of onion. American Journal of plant science 4, $890-893$

Sit, A. K., Bhattacharya, M., Sarkar, B. \& Arunachalam, V. (2007) Weed floristic composition in palm gardens in plains of eastern Himalayan region of West Bengal. Current Science 92, $1434-1439$.

Traoré, K., Soro, D., Camara, B. \& Sorho, F. (2010) Effectiveness of glyphosate herbicide in a juvenile oil palm plantation in Côte d' Ivoire. Journal of Animal and Plant Science 6 (1), $559-566$. 
TABLE 1

Initial observed weed species in the Fields of experimentation

\begin{tabular}{|c|c|c|c|c|}
\hline \multirow[t]{2}{*}{ Weed species } & \multirow[t]{2}{*}{ Family } & \multirow[t]{2}{*}{ Life cycle } & \multicolumn{2}{|c|}{ Morphology } \\
\hline & & & Dicot & Monocot. \\
\hline Acanthus montanus (Nees) T. Anders & Acanthaceae & Perennial & $\sqrt{ }$ & - \\
\hline Ageratum conyzoides Linn & Asteraceae & Perennial & $\sqrt{ }$ & - \\
\hline Alchornea cordifoliaMull.Arg. & Euphorbiaceae & Perennial & $\sqrt{ }$ & - \\
\hline Alchornea laxiflora(Benth.) Pax\& K. Hoffm & Euphorbiaceae & Perennial & $\sqrt{ }$ & - \\
\hline Alternantherabrasiliana( L.)Kuntze & Amaranthaceae & Perennial & $\sqrt{ }$ & - \\
\hline Amaranthus spinosus Linn. & Amaranthaceae & Annual & $\sqrt{ }$ & - \\
\hline Aspilia africana(Pers.) C.D. Adams & Compositae & Perennial & $\sqrt{ }$ & - \\
\hline Brachiaria deflexa (Schumach.) C.E. Hubbard & Poaceae & Annual & - & $\sqrt{ }$ \\
\hline Chromolaena odorata(L.) R.M. King \& Robinson & Asteraceae & Perennial & $\sqrt{ }$ & - \\
\hline Cleome viscosa $\mathrm{L}$. & Capperaraceae & Annual & $\sqrt{ }$ & - \\
\hline Cnestis ferruginea DC & Connaraceae & Perennial & $\sqrt{ }$ & - \\
\hline Combretum racemosumP. Beauv & Combretaceae & perennial & $\sqrt{ }$ & - \\
\hline Commelina difusa Burn f. Subsp.diffusa J.K Morton & Commelinaceae & Perennial & - & $\sqrt{ }$ \\
\hline Commelina benghalensis $\mathrm{L}$. & Commelinaceae & Perennial & - & $\sqrt{ }$ \\
\hline Corhorusolitorius L. & Malvaceae & Perennial & $\sqrt{ }$ & - \\
\hline Crassocephalum crepidoides(Benth) S.Moore & Asteraceae & Annual & $\sqrt{ }$ & - \\
\hline Cyperus esculentus Linn & Cyperaceae & perennial & - & $\sqrt{ }$ \\
\hline Cyperus rotundus Linn & Cyperaceae & Perennial & - & $\sqrt{ }$ \\
\hline DiodianscandensSw & Rubiaceae & Perennial & $\sqrt{ }$ & - \\
\hline Dissotis berecta(Guill.\&Perr.) & Melastomataceae & Perennial & $\sqrt{ }$ & - \\
\hline Eleusine indica Gaertn & Poaceae & Annual & - & $\sqrt{ }$ \\
\hline Erigeron floribundus H.B.\& K. & Asteraceae & Annual & $\sqrt{ }$ & - \\
\hline Euphorbia heterophylla Linn & Euphorbiaceae & Annual & $\sqrt{ }$ & - \\
\hline Euphorbia hirta Linn & Euphorbiaceae & Annual & $\sqrt{ }$ & - \\
\hline Fleurya aestuans(Linn.) ex Miq. & Urticaceae & Annual & $\sqrt{ }$ & - \\
\hline Heliotropiumindicum Linn & Boraginaceae & Annual & $\sqrt{ }$ & - \\
\hline Hyptis lanceolataPoir. & Lamiaceae & Annual & $\sqrt{ }$ & - \\
\hline HyptissuaveolensPoit. & Lamiaceae & Annual & $\sqrt{ }$ & - \\
\hline Ipomea asarifolia(Desr.) Roem. \&Schult. & Convolvucaceae & Perennial & $\sqrt{ }$ & - \\
\hline Ipomea involucrate P. Beauv. & Convolvucaceae & Perennial & $\sqrt{ }$ & - \\
\hline Melanthera scandens(Schum. \&Thonn.) Roberty & Asteraceae & Perennial & $\sqrt{ }$ & - \\
\hline Mitracarpus villosus(Sw.) & Rubiaceae & Annual & $\sqrt{ }$ & - \\
\hline Momordica charantia Linn & Cucubitaceae & Perennial & $\sqrt{ }$ & - \\
\hline Panicum maximum (Jacq.) R.D.Webster. & Poaceae & Perennial & - & $\sqrt{ }$ \\
\hline Pennisetum polystacchion Rich. & Poaceae & Annual & - & $\sqrt{ }$ \\
\hline Peperomia pellucida(Linn) H.B. \& K. & Piperaceae & Annual & $\sqrt{ }$ & - \\
\hline Phyllantus amarusSchum. \&Thonn. & Euphorbiaceae & Annual & $\sqrt{ }$ & - \\
\hline Physalis angulata Linn & Solanaceae & Annual & $\sqrt{ }$ & - \\
\hline Piper umbellatum Linn & Piperaceae & Perennial & $\sqrt{ }$ & - \\
\hline Rauwolfia vomitoria Afzel & Apocynaceae & Perennial & $\sqrt{ }$ & - \\
\hline Scoparia dulcis Linn & Plantaginaceae & Perennial & $\sqrt{ }$ & - \\
\hline Sida acutaBurm f. & Malvace & Perennial & $\sqrt{ }$ & - \\
\hline
\end{tabular}


TABLE 1 Continued.

\begin{tabular}{llllc}
\hline Weed species & Family & Life cycle & \multicolumn{2}{c}{ Morphology } \\
& & & Dicot. & Monocot. \\
\hline Solanum torvum L. & Solanaceae & Perennial & $\sqrt{2}$ & - \\
Solanium nigra Swartz & Solanaceae & Perennial & $\sqrt{ }$ & - \\
Synclisia scabridaMiers ex. Oliv. & Menispermaceae & Perennial & $\sqrt{ }$ & - \\
Synedrella nodifloraGaertn & Asteraceae & Annual & $\sqrt{ }$ & - \\
Talinium triangulare(Jacq.) Willd. & Portulacaceae & Perennial & $\sqrt{ }$ & - \\
Tabernaemontana Africana Hook & Apocynaceae & Perennial & $\sqrt{ }$
\end{tabular}

TABLE 2

Effect of herbicide treatment of control of individual weed species

\begin{tabular}{|c|c|c|c|c|c|c|c|c|c|c|c|c|}
\hline \multirow[b]{2}{*}{ Weed species } & \multicolumn{2}{|c|}{$\begin{array}{l}\text { Glyphosate at } 1.5 \\
\mathrm{~kg} \text { a.i. } \mathrm{ha}^{-1}\end{array}$} & \multicolumn{2}{|c|}{$\begin{array}{l}\text { Glyphosate + diuron at } \\
1.5+2 \text { a.i. } h a^{-1}\end{array}$} & \multicolumn{2}{|c|}{$\begin{array}{l}\text { Glufosinate ammonium } \\
\text { at } 0.4 \mathrm{~kg} \text { a.i } \mathrm{ha}^{-1}\end{array}$} & \multicolumn{2}{|c|}{$\begin{array}{l}\text { Glufosinate } \\
\text { ammonium at } 0.5 \\
\mathrm{~kg} \text { a.i ha } \mathrm{h}^{-1}\end{array}$} & \multicolumn{2}{|c|}{$\begin{array}{l}\text { Glufosinate } \\
\text { ammonium at } 0.5 \\
+ \text { indaziflam at } 0.4 \\
+0.4 \mathrm{kga}^{-i} \mathrm{ha}^{-1}\end{array}$} & \multicolumn{2}{|c|}{$\begin{array}{l}\text { Glufosinate am- } \\
\text { monium at } 0.5+ \\
\text { indaziflam at } 0.4+0.4 \\
\text { kga.i ha }^{-1}\end{array}$} \\
\hline & $\begin{array}{l}\% \\
\text { con- } \\
\text { trol }\end{array}$ & Exegesis & $\begin{array}{l}\% \\
\text { con- } \\
\text { trol }\end{array}$ & Exegesis & $\begin{array}{l}\% \text { con- } \\
\text { trol }\end{array}$ & Exegesis & $\begin{array}{l}\% \\
\text { con- } \\
\text { trol }\end{array}$ & $\begin{array}{l}\text { Exege- } \\
\text { sis }\end{array}$ & $\begin{array}{l}\% \\
\text { con- } \\
\text { trol }\end{array}$ & Exegesis & $\begin{array}{l}\% \\
\text { control }\end{array}$ & Exegesis \\
\hline $\begin{array}{l}\text { Acanthus mon- } \\
\text { tanus }\end{array}$ & 10 & $\begin{array}{l}\text { No } \\
\text { control }\end{array}$ & 10 & No effect & 10 & No effect & 10 & $\begin{array}{l}\text { No } \\
\text { effect }\end{array}$ & 10 & No effect & 10 & No effect \\
\hline $\begin{array}{l}\text { Ageratus co- } \\
\text { nyzoides }\end{array}$ & 90 & Good & 95 & Good & 70 & Moderate & 70 & $\begin{array}{l}\text { Mod- } \\
\text { erate }\end{array}$ & 75 & $\begin{array}{l}\text { Moder- } \\
\text { ate }\end{array}$ & 73 & Moderate \\
\hline $\begin{array}{l}\text { Alchornea cor- } \\
\text { difolia }\end{array}$ & 30 & Poor & 50 & Weediness & 10 & No effect & 10 & $\begin{array}{l}\text { No } \\
\text { effect }\end{array}$ & 10 & No effect & 10 & No effect \\
\hline Alchornea laxiflora & 30 & Poor & 50 & Weediness & 10 & No effect & 10 & $\begin{array}{l}\text { No } \\
\text { effect }\end{array}$ & 10 & No effect & 10 & No effect \\
\hline $\begin{array}{l}\text { Alternanthera } \\
\text { brasiliana }\end{array}$ & 100 & Perfect & 100 & Perfect & 85 & Acceptable & 85 & $\begin{array}{l}\text { Ac- } \\
\text { cept- } \\
\text { able }\end{array}$ & 85 & $\begin{array}{l}\text { Accept- } \\
\text { able }\end{array}$ & 85 & $\begin{array}{l}\text { Accept- } \\
\text { able }\end{array}$ \\
\hline $\begin{array}{l}\text { Amaranthus } \\
\text { spinosus }\end{array}$ & 100 & Perfect & 100 & Perfect & 70 & Moderate & 70 & $\begin{array}{l}\text { Mod- } \\
\text { erate }\end{array}$ & 70 & $\begin{array}{l}\text { Moder- } \\
\text { ate }\end{array}$ & 70 & Moderate \\
\hline Aspilia Africana & 100 & Perfect & 100 & Perfect & 85 & Acceptable & 85 & $\begin{array}{l}\text { Ac- } \\
\text { cept- } \\
\text { able }\end{array}$ & 90 & Good & 90 & Good \\
\hline Brachiaria deflexa & 50 & $\begin{array}{l}\text { Weedi- } \\
\text { ness }\end{array}$ & 60 & Weediness & 50 & weediness & 50 & $\begin{array}{l}\text { Weed- } \\
\text { iness }\end{array}$ & 70 & $\begin{array}{l}\text { Moder- } \\
\text { ate }\end{array}$ & 70 & Moderate \\
\hline $\begin{array}{l}\text { Chromolaena } \\
\text { odorata }\end{array}$ & 70 & $\begin{array}{l}\text { Moder- } \\
\text { ate }\end{array}$ & 70 & Moderate & 70 & Moderate & 70 & $\begin{array}{l}\text { Mod- } \\
\text { erate }\end{array}$ & 85 & $\begin{array}{l}\text { Accept- } \\
\text { able }\end{array}$ & 85 & $\begin{array}{l}\text { accept- } \\
\text { able }\end{array}$ \\
\hline Cleome viscosa & 80 & $\begin{array}{l}\text { Accept- } \\
\text { able }\end{array}$ & 100 & Perfect & 70 & Moderate & 70 & $\begin{array}{l}\text { Mod- } \\
\text { erate }\end{array}$ & 70 & $\begin{array}{l}\text { Moder- } \\
\text { ate }\end{array}$ & 70 & Moderate \\
\hline Cnestis ferruginea & 40 & Poor & 40 & Poor & 20 & Little effect & 20 & $\begin{array}{l}\text { Little } \\
\text { effect }\end{array}$ & 30 & Poor & 30 & Poor \\
\hline $\begin{array}{l}\text { Combretum } \\
\text { racemosum }\end{array}$ & 50 & $\begin{array}{l}\text { Weedi- } \\
\text { ness }\end{array}$ & 50 & Weediness & 10 & No control & 10 & $\begin{array}{l}\text { No } \\
\text { control }\end{array}$ & 10 & $\begin{array}{l}\text { No } \\
\text { control }\end{array}$ & 10 & $\begin{array}{l}\text { No } \\
\text { control }\end{array}$ \\
\hline Commelina difusa & 20 & $\begin{array}{l}\text { Little } \\
\text { effect }\end{array}$ & 30 & Poor & 20 & Little effect & 20 & $\begin{array}{l}\text { Little } \\
\text { effect }\end{array}$ & 20 & $\begin{array}{l}\text { Little } \\
\text { effect }\end{array}$ & 20 & $\begin{array}{l}\text { Little } \\
\text { effect }\end{array}$ \\
\hline $\begin{array}{l}\text { Commelina } \\
\text { benghalensis }\end{array}$ & 20 & $\begin{array}{l}\text { Little } \\
\text { effect }\end{array}$ & 20 & Little effect & 20 & Little effect & 20 & $\begin{array}{l}\text { Little } \\
\text { effect }\end{array}$ & 20 & $\begin{array}{l}\text { Little } \\
\text { effect }\end{array}$ & 20 & $\begin{array}{l}\text { Little } \\
\text { effect }\end{array}$ \\
\hline Corhorus olitorius & 90 & Good & 100 & Perfect & 75 & Moderate & 75 & $\begin{array}{l}\text { Mod- } \\
\text { erate }\end{array}$ & 85 & $\begin{array}{l}\text { Accept- } \\
\text { able }\end{array}$ & 85 & $\begin{array}{l}\text { Accept- } \\
\text { able }\end{array}$ \\
\hline $\begin{array}{l}\text { Crassocephalum } \\
\text { crepidoides }\end{array}$ & 80 & $\begin{array}{l}\text { Accept- } \\
\text { able }\end{array}$ & 100 & Perfect & 70 & Moderate & 70 & $\begin{array}{l}\text { Mod- } \\
\text { erate }\end{array}$ & 85 & $\begin{array}{l}\text { Accept- } \\
\text { able }\end{array}$ & 85 & $\begin{array}{l}\text { Accept- } \\
\text { able }\end{array}$ \\
\hline Cyperus esculentus & 90 & Good & 100 & Perfect & 70 & Moderate & 70 & $\begin{array}{l}\text { Mod- } \\
\text { erate }\end{array}$ & 70 & $\begin{array}{l}\text { Moder- } \\
\text { ate }\end{array}$ & 70 & Moderate \\
\hline Cyperus rotundus & 90 & Good & 98 & Perfect & 70 & Moderate & 70 & $\begin{array}{l}\text { Mod- } \\
\text { erate }\end{array}$ & 85 & $\begin{array}{l}\text { Moder- } \\
\text { ate }\end{array}$ & 70 & Moderate \\
\hline
\end{tabular}




\begin{tabular}{|c|c|c|c|c|c|c|c|c|c|c|c|c|}
\hline Diodia scandens & 98 & Perfect & 100 & Perfect & 70 & Moderate & 70 & $\begin{array}{l}\text { Mod- } \\
\text { erate }\end{array}$ & 85 & $\begin{array}{l}\text { Accept- } \\
\text { able }\end{array}$ & 85 & $\begin{array}{l}\text { accept- } \\
\text { able }\end{array}$ \\
\hline Dissotis erecta & 90 & Good & 100 & Perfect & 70 & Moderate & 70 & $\begin{array}{l}\text { Mod- } \\
\text { erate }\end{array}$ & 70 & $\begin{array}{l}\text { Moder- } \\
\text { ate }\end{array}$ & 70 & Moderate \\
\hline Eleusine indica & 90 & Good & 100 & Perfect & 85 & Acceptable & 85 & $\begin{array}{l}\text { Ac- } \\
\text { cept- } \\
\text { able }\end{array}$ & 85 & $\begin{array}{l}\text { Accept- } \\
\text { able }\end{array}$ & 85 & $\begin{array}{l}\text { Accept- } \\
\text { able }\end{array}$ \\
\hline $\begin{array}{l}\text { Erigeron flori- } \\
\text { bundus }\end{array}$ & 90 & Good & 100 & Perfect & 75 & Moderate & 75 & $\begin{array}{l}\text { Mod- } \\
\text { erate }\end{array}$ & 75 & $\begin{array}{l}\text { Moder- } \\
\text { ate }\end{array}$ & 75 & Moderate \\
\hline $\begin{array}{l}\text { Euphorbia hetero- } \\
\text { phylla }\end{array}$ & 20 & $\begin{array}{l}\text { Little } \\
\text { effect }\end{array}$ & 20 & Little effect & 10 & No effect & 10 & $\begin{array}{l}\text { No } \\
\text { effect }\end{array}$ & 10 & No effect & 10 & No effect \\
\hline Euphorbia hirta & 100 & Perfect & 100 & Perfect & 85 & Acceptable & 83 & $\begin{array}{l}\text { Ac- } \\
\text { cept- } \\
\text { able }\end{array}$ & 83 & $\begin{array}{l}\text { Accept- } \\
\text { able }\end{array}$ & 83 & $\begin{array}{l}\text { Accept- } \\
\text { able }\end{array}$ \\
\hline Fleurya aestuans & 100 & Perfect & 100 & Perfect & 85 & Acceptable & 85 & $\begin{array}{l}\text { Ac- } \\
\text { cept- } \\
\text { able }\end{array}$ & 85 & $\begin{array}{l}\text { Accept- } \\
\text { able }\end{array}$ & 85 & $\begin{array}{l}\text { Accept- } \\
\text { able }\end{array}$ \\
\hline $\begin{array}{l}\text { Heliotropium } \\
\text { indicum }\end{array}$ & 60 & $\begin{array}{l}\text { Weedi- } \\
\text { ness }\end{array}$ & 62 & Weediness & 40 & Poor & 40 & Poor & 40 & Poor & 40 & Poor \\
\hline Hyptis lanceolata & 100 & Perfect & 100 & Perfect & 70 & Moderate & 72 & $\begin{array}{l}\text { Mod- } \\
\text { erate }\end{array}$ & 72 & $\begin{array}{l}\text { Moder- } \\
\text { ate }\end{array}$ & 72 & Moderate \\
\hline Hyptis suaveolens & 100 & Perfect & 100 & Perfect & 70 & Moderate & 70 & $\begin{array}{l}\text { Mod- } \\
\text { erate }\end{array}$ & 70 & $\begin{array}{l}\text { Moder- } \\
\text { ate }\end{array}$ & 70 & Moderate \\
\hline Ipomea asarifolia & 80 & $\begin{array}{l}\text { Accept- } \\
\text { able }\end{array}$ & 100 & Perfect & 70 & Moderate & 73 & $\begin{array}{l}\text { Mod- } \\
\text { erate }\end{array}$ & 73 & $\begin{array}{l}\text { Moder- } \\
\text { ate }\end{array}$ & 73 & Moderate \\
\hline $\begin{array}{l}\text { Impomea invo- } \\
\text { lucrate }\end{array}$ & 85 & $\begin{array}{l}\text { Accept- } \\
\text { able }\end{array}$ & 100 & Perfect & 85 & Acceptable & 85 & $\begin{array}{l}\text { Ac- } \\
\text { cept- } \\
\text { able }\end{array}$ & 85 & $\begin{array}{l}\text { Accept- } \\
\text { able }\end{array}$ & 85 & $\begin{array}{l}\text { Accept- } \\
\text { able }\end{array}$ \\
\hline $\begin{array}{l}\text { Melanthera } \\
\text { scandens }\end{array}$ & 85 & $\begin{array}{l}\text { Accept- } \\
\text { able }\end{array}$ & 100 & Perfect & 70 & Moderate & 70 & $\begin{array}{l}\text { Mod- } \\
\text { erate }\end{array}$ & 70 & $\begin{array}{l}\text { Moder- } \\
\text { ate }\end{array}$ & 70 & Moderate \\
\hline $\begin{array}{l}\text { Mitracarpus } \\
\text { villosus }\end{array}$ & 75 & $\begin{array}{l}\text { Moder- } \\
\text { ate }\end{array}$ & 95 & Good & 70 & Moderate & 75 & $\begin{array}{l}\text { Mod- } \\
\text { erate }\end{array}$ & 75 & $\begin{array}{l}\text { Moder- } \\
\text { ate }\end{array}$ & 75 & Moderate \\
\hline $\begin{array}{l}\text { Momordica } \\
\text { charantia }\end{array}$ & 100 & Perfect & 100 & Perfect & 85 & Acceptable & 85 & $\begin{array}{l}\text { Ac- } \\
\text { cept- } \\
\text { able }\end{array}$ & 85 & $\begin{array}{l}\text { Accept- } \\
\text { able }\end{array}$ & 85 & $\begin{array}{l}\text { Accept- } \\
\text { able }\end{array}$ \\
\hline $\begin{array}{l}\text { Panicum max- } \\
\text { imum }\end{array}$ & 100 & Perfect & 100 & Perfect & 80 & Acceptable & 85 & $\begin{array}{l}\text { Ac- } \\
\text { cept- } \\
\text { able } \\
\text { Ac- }\end{array}$ & 85 & $\begin{array}{l}\text { Accept- } \\
\text { able }\end{array}$ & 85 & $\begin{array}{l}\text { Accept- } \\
\text { able }\end{array}$ \\
\hline $\begin{array}{l}\text { Pennisetum } \\
\text { polystcchion }\end{array}$ & 100 & Perfect & 100 & Perfect & 80 & Acceptable & 85 & $\begin{array}{l}\text { cept- } \\
\text { able }\end{array}$ & 85 & $\begin{array}{l}\text { Accept- } \\
\text { able }\end{array}$ & 85 & $\begin{array}{l}\text { Accept- } \\
\text { able }\end{array}$ \\
\hline $\begin{array}{l}\text { Peperomia } \\
\text { pellucida }\end{array}$ & 45 & $\begin{array}{l}\text { Weedi- } \\
\text { ness }\end{array}$ & 60 & Weediness & 50 & Weediness & 50 & $\begin{array}{l}\text { Weed- } \\
\text { iness }\end{array}$ & 50 & $\begin{array}{l}\text { Weedi- } \\
\text { ness }\end{array}$ & 50 & $\begin{array}{l}\text { Weedi- } \\
\text { ness }\end{array}$ \\
\hline Phyllantus amarus & 80 & $\begin{array}{l}\text { Accept- } \\
\text { able }\end{array}$ & 95 & Good & 85 & Acceptable & 85 & $\begin{array}{l}\text { Ac- } \\
\text { cept- } \\
\text { able }\end{array}$ & 85 & $\begin{array}{l}\text { Accept- } \\
\text { able }\end{array}$ & 85 & $\begin{array}{l}\text { Accept- } \\
\text { able }\end{array}$ \\
\hline Physali angulate & 75 & $\begin{array}{l}\text { Moder- } \\
\text { ate }\end{array}$ & 95 & Good & 85 & Acceptable & 85 & $\begin{array}{l}\text { Ac- } \\
\text { cept- } \\
\text { able }\end{array}$ & 85 & $\begin{array}{l}\text { Accept- } \\
\text { able }\end{array}$ & 85 & $\begin{array}{l}\text { Accept- } \\
\text { able }\end{array}$ \\
\hline Piper umbellatum & 100 & Perfect & 100 & Perfect & 70 & Moderate & 70 & $\begin{array}{l}\text { Mod- } \\
\text { erate }\end{array}$ & 70 & $\begin{array}{l}\text { Moder- } \\
\text { ate }\end{array}$ & 70 & Moderate \\
\hline $\begin{array}{l}\text { Rauwolfia } \\
\text { vomitoria }\end{array}$ & 10 & $\begin{array}{l}\text { No } \\
\text { control }\end{array}$ & 15 & Little effect & 65 & Moderate & 65 & $\begin{array}{l}\text { Mod- } \\
\text { erate }\end{array}$ & 63 & $\begin{array}{l}\text { Moder- } \\
\text { ate }\end{array}$ & 67 & Moderate \\
\hline Scoparia dulcis & 75 & $\begin{array}{l}\text { Moder- } \\
\text { ate }\end{array}$ & 85 & Acceptable & 85 & Acceptable & 85 & $\begin{array}{l}\text { Ac- } \\
\text { cept- } \\
\text { able }\end{array}$ & 85 & $\begin{array}{l}\text { Accept- } \\
\text { able }\end{array}$ & 85 & $\begin{array}{l}\text { Accept- } \\
\text { able }\end{array}$ \\
\hline Sida acuta & 65 & $\begin{array}{l}\text { Moder- } \\
\text { ate }\end{array}$ & 65 & Moderate & 50 & Weediness & 50 & $\begin{array}{l}\text { Weed- } \\
\text { iness }\end{array}$ & 50 & $\begin{array}{l}\text { Weedi- } \\
\text { ness }\end{array}$ & 50 & $\begin{array}{l}\text { Weedi- } \\
\text { ness }\end{array}$ \\
\hline Solanum torvum & 97 & Perfect & 100 & Perfect & 65 & Moderate & 65 & $\begin{array}{l}\text { Mod- } \\
\text { erate }\end{array}$ & 65 & $\begin{array}{l}\text { Moder- } \\
\text { ate }\end{array}$ & 65 & Moderate \\
\hline
\end{tabular}


TABLE 2 continued

\begin{tabular}{|c|c|c|c|c|c|c|c|c|c|c|c|c|}
\hline \multirow[t]{2}{*}{ Weed species } & \multicolumn{2}{|c|}{$\begin{array}{l}\text { Glyphosate at } 1.5 \\
\mathrm{~kg} \text { a.i. } \mathrm{ha}^{-1}\end{array}$} & \multicolumn{2}{|c|}{$\begin{array}{l}\text { Glyphosate }+ \\
\text { diuron at } 1.5+2 \\
\text { a.i. } \text { ha }^{-1}\end{array}$} & \multicolumn{2}{|c|}{$\begin{array}{l}\text { Glufosinate } \\
\text { ammonium at } 0.4 \mathrm{~kg} \\
\text { a.i ha }{ }^{-1}\end{array}$} & \multicolumn{2}{|c|}{$\begin{array}{l}\text { Glufosinate am- } \\
\text { monium at } 0.5 \mathrm{~kg} \\
\text { a.i ha-1 }\end{array}$} & \multicolumn{2}{|c|}{$\begin{array}{l}\text { Glufosinate } \\
\text { ammonium at } 0.5 \\
+ \text { indaziflam at } 0.4 \\
+0.4 \mathrm{kga}^{\mathrm{i}} \mathrm{ha}^{-1}\end{array}$} & \multicolumn{2}{|c|}{$\begin{array}{l}\text { Glufosinate } \\
\text { ammonium at } 0.5 \\
+ \text { indaziflam at } 0.4 \\
+0.4 \mathrm{kgai}^{\mathrm{h} \mathrm{ha}^{-1}}\end{array}$} \\
\hline & $\begin{array}{l}\% \\
\text { con- } \\
\text { trol }\end{array}$ & $\begin{array}{l}\text { Exege- } \\
\text { sis }\end{array}$ & $\begin{array}{l}\% \\
\text { con- } \\
\text { trol }\end{array}$ & Exegesis & $\begin{array}{l}\% \\
\text { con- } \\
\text { trol }\end{array}$ & Exegesis & $\begin{array}{l}\% \text { con- } \\
\text { trol }\end{array}$ & $\begin{array}{l}\text { Exege- } \\
\text { sis }\end{array}$ & $\begin{array}{l}\% \\
\text { control }\end{array}$ & Exegesis & $\begin{array}{l}\% \\
\text { con- } \\
\text { trol }\end{array}$ & $\begin{array}{l}\text { Exege- } \\
\text { sis }\end{array}$ \\
\hline Solanium nigra & 95 & Good & 95 & Good & 65 & Moderate & 65 & $\begin{array}{l}\text { Moder- } \\
\text { ate }\end{array}$ & 65 & Moderate & 65 & $\begin{array}{l}\text { Moder- } \\
\text { ate }\end{array}$ \\
\hline $\begin{array}{l}\text { Synclisia } \\
\text { scabrida }\end{array}$ & 35 & Poor & 32 & Poor & 35 & Poor & 35 & Poor & 35 & Poor & 35 & Poor \\
\hline $\begin{array}{l}\text { Synedrella } \\
\text { nodiflora }\end{array}$ & 90 & Good & 90 & Good & 70 & Moderate & 70 & $\begin{array}{l}\text { Moder- } \\
\text { ate }\end{array}$ & 70 & Moderate & 70 & $\begin{array}{l}\text { Moder- } \\
\text { ate }\end{array}$ \\
\hline $\begin{array}{l}\text { Talinium trian- } \\
\text { gulare }\end{array}$ & 20 & $\begin{array}{l}\text { Little } \\
\text { effect }\end{array}$ & 20 & $\begin{array}{l}\text { Little } \\
\text { effect }\end{array}$ & 20 & $\begin{array}{l}\text { Little } \\
\text { effect }\end{array}$ & 20 & $\begin{array}{l}\text { Little } \\
\text { effect }\end{array}$ & 20 & $\begin{array}{l}\text { Little } \\
\text { effect }\end{array}$ & 20 & $\begin{array}{l}\text { Little } \\
\text { effect }\end{array}$ \\
\hline $\begin{array}{l}\text { Tabernaemon- } \\
\text { tana africana }\end{array}$ & 10 & $\begin{array}{l}\text { No } \\
\text { effect }\end{array}$ & 20 & $\begin{array}{l}\text { Little } \\
\text { effect }\end{array}$ & 95 & Good & 100 & Perfect & 100 & Perfect & 100 & Perfect \\
\hline
\end{tabular}

TABLE 3

Emerged weed species within the 24 weeks of data collection after herbicide treatments

\begin{tabular}{|c|c|c|}
\hline Treatments & $\begin{array}{l}\text { Rate (kg a.i. } \\
\left.h a^{-1}\right)\end{array}$ & Emerged weed species $\left(m^{-2}\right)$ \\
\hline Glyphosate & 1.5 & $\begin{array}{l}\text { Aspilia Africana, Brachiaria deflexa, Cleome viscose, Cnestis ferru- } \\
\text { ginea, Combretum racemosum, Commelina difusa, Crassocephalum } \\
\text { crepidoides, Corhorus olitorius, Cyperus esculentus, Cyperus rotun- } \\
\text { dus, Alternanthera brasiliana, Amaranthus spinosus, Euphorbia hir- } \\
\text { ta, Erigeron floribundus, Euphorbia heterophylla, Eleusine indica, } \\
\text { Dissotis erecta, Alchornea cordifolia, Alchornea laxiflora, Panicum } \\
\text { maximum, Peperomia pellucida, Phyllantus amarus, Pennisetum } \\
\text { polystcchion, Talinium triangulare, Synclisia scabrida, Synedrella } \\
\text { nodiflora, Tabernaemontana Africana, Sida acuta }\end{array}$ \\
\hline
\end{tabular}

Density of

emerged weed species $/ \mathrm{m}^{2}$

2, 1, 1, 1, 2, 2,

$1,1,3,2,3,2$,

$2,1,1,1,1,1,1$, 2, 2, 1, 1, 3,1, 1, 3,3 ,

Acanthus montanus, Alchornea cordifolia, Alchornea laxiflora, Aspilia Africana, Brachiaria deflexa, Chromolaena odorata, Cyperus

Glyphosate
Diuron esculentus, Cyperus rotundus, Eleusine indica, Euphorbia heterophylla, Fleurya aestuans, Rauwolfia vomitoria, Scoparia dulcis, Sida acuta, Heliotropium indicum, Cnestis ferruginea, Combretum racemosum, Commelina difusa, Melanthera scandens, Synclisia scabrida, Talinium triangulare, Tabernaemontana Africana, Momordica charantia, Peperomia pellucida

Centrosema pubescens, Thamatococucus daniellii, icacina trichantha, Solanium nigra, Synclisia scabrida, Solanum torvum, Fleurya aestuans, Acanthus montanus, Ageratus conyzoides, Alchornea cor-

Glufosinate ammonium difolia, Alchornea laxiflora, Combretum racemosum, Commelina difusa, Commelina benghalensis, Aspilia Africana, Brachiaria deflexa, Cleome viscosa, Cnestis ferruginea, Erigeron floribundus, Euphorbia heterophylla, Euphorbia hirta, Panicum maximum, Pennisetum polystcchion.
$12,1,2,1,1,1$, $1,1,1,1,1,1$, $2,1,1,2,1,1,1$ $2,1,1,2$.

$3,3,3,2,2,1$, $5,2,4,1,2,2$, $2,2,8,1,2,1$, $2,2,6,6,2$ 
Glufosinate ammonium

Glufosinate ammonium + indaziflam

Glufosinate ammonium + indaziflam

Weedy plot
0.4

$0.4+0.04$

\section{TABLE 3 continued}

Centrosema pubescens, Thamatococucus daniellii, icacina trichantha, Solanium nigra, Synclisia scabrida, Solanum torvum, Fleurya aestuans, Acanthus montanus, Ageratus conyzoides, Alchornea cordifolia, Alchornea laxiflora, Combretum racemosum, Commelina difusa, Commelina benghalensis, Aspilia Africana, Brachiaria deflexa, Cleome viscosa, Cnestis ferruginea, Erigeron floribundus, Euphorbia heterophylla, Euphorbia hirta, Panicum maximum, Pennisetum polystcchion.

Centrosema pubescens, Thamatococucus daniellii, icacina trichantha, Solanium nigra, Synclisia scabrida, Solanum torvum, Fleurya aestuans, Acanthus montanus, Alchornea cordifolia, Alchornea laxiflora, Combretum racemosum, Commelina difusa, Commelina benghalensis, Brachiaria deflexa, Cleome viscosa, Cnestis ferruginea, Erigeron floribundus, Euphorbia heterophylla, Euphorbia hirta, Panicum maximum, Pennisetum polystcchion, Rauwolfia vomitoria., Piper umbellatum, Melanthera scandens, Erigeron floribundus

Thamatococucus daniellii, icacina trichantha, Solanium nigra, Synclisia scabrida, Solanum torvum, Fleurya aestuans, Acanthus montanus, Alchornea cordifolia, Alchornea laxiflora, Combretum racemosum, Commelina difusa, Commelina benghalensis, Brachiaria deflexa, Cleome viscosa, Cnestis ferruginea, Erigeron floribundus, Euphorbia heterophylla, Euphorbia hirta, Panicum maximum, Pennisetum polystcchion, Rauwolfia vomitoria, Solanium nigra, Piper umbellatum, Mitracarpus villosus, Euphorbia heterophylla, Melanthera scandens, Mitracarpus villosus.

Acanthus montanus, Ageratus conyzoides, Alchornea cordifolia, Alternanthera brasiliana, Amaranthus spinosus, Aspilia Africana, Brachiaria deflexa, Chromolaena odorata, Cnestis ferruginea, Combretum racemosum, Commelina difusa, Crassocephalum crepidoides, Cyperus esculentus, Cyperus rotundus, Dissotis erecta, Eleusine indica, Erigeron floribundus, Euphorbia heterophylla, Euphorbia hirta, Heliotropium indicum, Hyptis lanceolata, Hyptis suaveolens, Ipomea asarifolia, Impomea involucrate, Melanthera scandens, Mitracarpus villosus, Panicum maximum, Pennisetum polystcchion, Peperomia pellucid, Phyllantus amarus, Physali angulata, Rauwolfia vomitoria, Scoparia dulcis, Sida acuta, Solanum torvum, Solanium nigra, Synclisia scabrida, Synedrella nodiflora, Talinium triangulare, Tabernaemontana Africana.
$5,2,3,2,4,3,4$, $1,3,6,1,3,3$, 2, 7, 3, 1, 1, 1, $1,3,3,2$.

2, 1, 1, 1, 1, 1, 2, 1, 1, 1, 2, 1, $1,2,1,1,1,1,1$, $1,1,1,1,2,1$

1, 2,1, 1, 1, 1 1, $1,1,2,2,1,1$, 1, 1, 1', 2, 1, 1, 1, 1, 1, 1, 1,

2,6, 1, 4, 5,8, 3, $4,2,4,5,3,6$, $6,4,5,6,2,7$, 4, 5, 3, 4, 4,3, 8, 4, 6, 3,3, 4, 4, $2,4,3,2,5,2$, 3,6 . 
TABLE 4

Efficacy of herbicide treatments on weed control in oil palm.

\begin{tabular}{|c|c|c|c|c|c|c|c|}
\hline \multirow[t]{3}{*}{ Treatment } & \multirow{3}{*}{$\begin{array}{l}\mathrm{Kg} \\
\mathrm{ha}^{-1}\end{array}$} & \multicolumn{6}{|c|}{ Weeks after treatment } \\
\hline & & 4 & 8 & & 12 & 20 & 24 \\
\hline & & \multicolumn{6}{|c|}{ Visual weed control rating } \\
\hline Control & 0.0 & $0.0 \mathrm{~d}$ & $0.0 \mathrm{~d}$ & 0.0 & $0.0 \mathrm{~g}$ & $0.0 \mathrm{~d}$ & $0.0 \mathrm{~d}$ \\
\hline Glyphosate & 1.5 & $85.0 \mathrm{~b}$ & $86.7 \mathrm{~b}$ & $73.0 \mathrm{~b}$ & $45.3 \mathrm{~d}$ & $25.0 \mathrm{~b}$ & $12.7 \mathrm{bc}$ \\
\hline Glyphosate + Diuron & $1.5+2$ & $88.0 \mathrm{a}$ & $90.7 \mathrm{a}$ & $89.0 \mathrm{a}$ & $68.7 \mathrm{c}$ & $52.3 \mathrm{a}$ & $32.7 \mathrm{a}$ \\
\hline Glufosinate ammonium & 0.4 & $80.7 \mathrm{c}$ & $72.7 \mathrm{c}$ & $57.3 \mathrm{c}$ & $32.3 \mathrm{e}$ & $21.7 \mathrm{c}$ & $10.7 \mathrm{c}$ \\
\hline Glufosinate ammonium & 0.5 & $80.7 \mathrm{c}$ & $72.0 \mathrm{c}$ & $57.3 \mathrm{c}$ & $36.3 \mathrm{f}$ & $26.0 \mathrm{~b}$ & $14.0 \mathrm{~b}$ \\
\hline $\begin{array}{l}\text { Glufosinate ammoium + indazi- } \\
\text { flam (tank mix) }\end{array}$ & $0.4+0.04$ & $87.7 \mathrm{a}$ & $90.7 \mathrm{a}$ & $91.0 \mathrm{a}$ & $75.7 \mathrm{a}$ & $53.7 \mathrm{a}$ & $32.3 \mathrm{a}$ \\
\hline $\begin{array}{l}\text { Glufosinate ammonium + inda- } \\
\text { ziflam (tank mix) }\end{array}$ & $0.5+0.04$ & $86.3 \mathrm{ab}$ & $91.0 \mathrm{a}$ & $91.0 \mathrm{a}$ & $74.0 \mathrm{a}$ & $53.3 \mathrm{a}$ & $32.3 \mathrm{a}$ \\
\hline S.E & & 0.7 & 1.1 & 1.4 & 1.3 & 1.4 & 1.0 \\
\hline $\mathrm{CV}$ & & 1.7 & 1.9 & 2.6 & 3.4 & 5.1 & 6.6 \\
\hline
\end{tabular}

TABLE 5

Efficacy of herbicide treatments on weed biomass suppression in oil palm

\begin{tabular}{|c|c|c|c|c|c|c|c|}
\hline \multirow{3}{*}{ Treatment } & \multirow{3}{*}{ Kg a.i. $h a^{-1}$} & \multicolumn{6}{|c|}{ Weeks after treatment } \\
\hline & & 4 & 8 & 12 & 16 & 20 & 24 \\
\hline & & \multicolumn{6}{|c|}{ Biomass of weed regrowth $\left(\mathrm{g} \mathrm{m}^{-2}\right)$} \\
\hline Control & 0.0 & $1240.0 \mathrm{a}$ & $1333.0 \mathrm{a}$ & $1586.7 \mathrm{a}$ & $1646.7 \mathrm{a}$ & $1703.3 \mathrm{a}$ & $1733.3 \mathrm{a}$ \\
\hline Glyphosate & 1.5 & $163.0 \mathrm{c}$ & $137 \mathrm{c}$ & $241.0 \mathrm{c}$ & $580.3 \mathrm{~d}$ & $896.0 \mathrm{c}$ & $1224.7 \mathrm{c}$ \\
\hline $\begin{array}{l}\text { Glyphosate + } \\
\text { Diuron }\end{array}$ & $1.5+2$ & $162.0 \mathrm{c}$ & $151 \mathrm{c}$ & $160.3 \mathrm{~d}$ & $232.3 \mathrm{e}$ & $367.0 \mathrm{~d}$ & $677.7 \mathrm{~d}$ \\
\hline $\begin{array}{l}\text { Glufosinate } \\
\text { ammonium }\end{array}$ & 0.4 & $275.0 \mathrm{~b}$ & $332 b$ & $485.3 b$ & $736.7 \mathrm{~b}$ & $910.7 b$ & $1633.0 \mathrm{~b}$ \\
\hline $\begin{array}{l}\text { Glufosinate } \\
\text { ammonium }\end{array}$ & 0.5 & $263.0 \mathrm{~b}$ & $206 b$ & $444.7 b$ & $709.3 \mathrm{c}$ & $897.7 \mathrm{c}$ & $1194.3 \mathrm{c}$ \\
\hline $\begin{array}{l}\text { Glufosiante } \\
\text { ammonium } \\
+ \text { indaziflam } \\
\text { (tank mix) }\end{array}$ & $0.4+0.04$ & $159.0 \mathrm{c}$ & $149 \mathrm{c}$ & $154.3 \mathrm{~d}$ & $221.7 \mathrm{e}$ & $365.3 \mathrm{~d}$ & $714.3 \mathrm{~d}$ \\
\hline $\begin{array}{l}\text { Glufosinate } \\
\text { ammonium } \\
+ \text { indaziflam } \\
\text { (tank mix) }\end{array}$ & $0.5+0.04$ & $159.0 \mathrm{c}$ & $149 \mathrm{c}$ & $154.0 \mathrm{~d}$ & $225.0 \mathrm{e}$ & $369.0 \mathrm{~d}$ & $708.7 \mathrm{~d}$ \\
\hline S.E & & 41.4 & 63.9 & 22.49 & 5.61 & 5.8 & 20.83 \\
\hline $\mathrm{CV}$ & & 14.7 & 22.3 & 6.0 & 1.1 & 0.9 & 2.3 \\
\hline
\end{tabular}


TABLE 6

Effectiveness of herbicide treatments on weed control in oil palm.

\begin{tabular}{|c|c|c|c|c|c|c|c|}
\hline \multirow{3}{*}{ Treatment } & \multirow{3}{*}{$K g$ a.i. $h a^{-1}$} & \multicolumn{5}{|c|}{ Weeks after treatment } & \multirow[b]{2}{*}{24} \\
\hline & & 4 & 8 & 12 & 16 & 20 & \\
\hline & & \multicolumn{2}{|c|}{ Weed control efficiency } & $\%$ & & & \\
\hline Control & 0.0 & 0.0 & 0.0 & 0.0 & 0.0 & 0.0 & 0.0 \\
\hline Glyphosate & 1.5 & 87.0 & 90.0 & 85.0 & 67.2 & 47.4 & 29.3 \\
\hline $\begin{array}{l}\text { Glyphosate + } \\
\text { Diuron }\end{array}$ & $1.5+2$ & 87.0 & 89.0 & 90.0 & 86.9 & 78.5 & 60.9 \\
\hline $\begin{array}{l}\text { Glufosinate } \\
\text { ammonium }\end{array}$ & 0.4 & 78.0 & 75.0 & 69.4 & 55.3 & 46.5 & 5.7 \\
\hline $\begin{array}{l}\text { Glufosinate } \\
\text { ammonium }\end{array}$ & 0.5 & 78.0 & 85.0 & 72.0 & 56.9 & 47.3 & 31.1 \\
\hline $\begin{array}{l}\text { Glufosinate } \\
\text { ammonium }+ \\
\text { indaziflam (tank } \\
\text { mix) }\end{array}$ & $0.4+0.04$ & 87.0 & 88.0 & 90.0 & 86.5 & 78.6 & 58.8 \\
\hline $\begin{array}{l}\text { Glufosinate } \\
\text { ammonium }+ \\
\text { indaziflam (tank } \\
\text { mix) }\end{array}$ & $0.5+0.04$ & 87.0 & 88.0 & 90.0 & 86.3 & 78.3 & 59.1 \\
\hline
\end{tabular}

TABLE 7

Effect of herbicide treatments on weed coverage in oil palm.

\begin{tabular}{|c|c|c|c|c|c|c|c|}
\hline \multirow[t]{3}{*}{ Treatment } & \multirow{3}{*}{$\begin{array}{l}K g \text { a.i. } \\
h a^{-1}\end{array}$} & \multicolumn{6}{|c|}{ Weeks after treatment } \\
\hline & & 4 & 8 & 12 & 16 & 20 & 24 \\
\hline & & \multicolumn{6}{|c|}{ Weed coverage (\%) } \\
\hline Control & 0.0 & $100.0 \mathrm{a}$ & $100.0 \mathrm{a}$ & $100.0 \mathrm{a}$ & $100.0 \mathrm{a}$ & $100.0 \mathrm{a}$ & $100.0 \mathrm{a}$ \\
\hline Glyphosate & 1.5 & $16.7 b$ & $14.7 \mathrm{c}$ & $37.7 \mathrm{c}$ & $66.3 b$ & $74.0 \mathrm{c}$ & $87.3 b$ \\
\hline $\begin{array}{l}\text { Glyphosate + } \\
\text { Diuron }\end{array}$ & $1.5+2$ & $13.7 \mathrm{e}$ & $12.7 \mathrm{c}$ & $14.7 \mathrm{~d}$ & $45.3 \mathrm{~d}$ & $58.7 \mathrm{~d}$ & $69.3 \mathrm{~d}$ \\
\hline $\begin{array}{l}\text { Glufosinate ammo- } \\
\text { nium }\end{array}$ & 0.4 & $19.0 \mathrm{~b}$ & $29.7 b$ & $45.0 \mathrm{~b}$ & $67.7 \mathrm{c}$ & $81.3 b$ & $91.7 \mathrm{~b}$ \\
\hline $\begin{array}{l}\text { Glufosinate ammo- } \\
\text { nium }\end{array}$ & 0.5 & $18.0 \mathrm{c}$ & $30.0 \mathrm{~b}$ & $44.0 \mathrm{~b}$ & $61.0 \mathrm{c}$ & $80.7 b$ & $72.7 \mathrm{c}$ \\
\hline $\begin{array}{l}\text { Glufosinate ammo- } \\
\text { niaum + indaziflam } \\
\text { (tank mix) }\end{array}$ & $0.4+0.04$ & $15.3 \mathrm{~d}$ & $12.0 \mathrm{c}$ & $13.3 \mathrm{~d}$ & $47.7 \mathrm{~d}$ & $59.0 \mathrm{~d}$ & $71.3 \mathrm{c}$ \\
\hline $\begin{array}{l}\text { Glufosinate ammo- } \\
\text { niaum + indaziflam } \\
\text { (tank mix) }\end{array}$ & $0.5+0.04$ & $13.7 \mathrm{e}$ & $13.3 \mathrm{c}$ & $13.0 \mathrm{~d}$ & $44.7 \mathrm{~d}$ & $61.0 \mathrm{~d}$ & $74.3 \mathrm{c}$ \\
\hline S.E & & 0.6 & 1.0 & 1.7 & 2.8 & 2.0 & 9.2 \\
\hline $\mathrm{CV}$ & & 2.5 & 4.2 & 5.5 & 5.7 & 3.4 & 13.9 \\
\hline
\end{tabular}


TABLE 8

Effect of herbicides treatments to oil palm fronds

\begin{tabular}{|c|c|c|c|c|c|c|c|c|}
\hline \multirow{3}{*}{ Treatment } & \multirow{3}{*}{$\begin{array}{l}K g \\
h a^{-1}\end{array}$} & \multicolumn{7}{|c|}{ Toxicity } \\
\hline & & \multicolumn{7}{|c|}{ Weeks after treatment } \\
\hline & & 4 & 8 & & 12 & 16 & 20 & 24 \\
\hline Herbicide free plot (control) & 0.0 & 1 & 1 & 1 & 1 & 1 & & 1 \\
\hline Glyphosate & 1.5 & 3 & 2 & 1 & 1 & 1 & & 1 \\
\hline Glyphosate + Diuron & $1.5+2$ & 2 & 2 & 1 & 1 & 1 & & 1 \\
\hline Glufosinate ammonium & 0.4 & 1 & 1 & 1 & 1 & 1 & & 1 \\
\hline Glufosinate ammonium & 0.5 & 1 & 1 & 1 & 1 & 1 & & 1 \\
\hline $\begin{array}{l}\text { Glufosinate ammonium }+ \text { indaziflam } \\
\text { (Tank mix) }\end{array}$ & $0.5+0.04$ & 1 & 1 & 1 & 1 & 1 & & 1 \\
\hline $\begin{array}{l}\text { Glufosinate ammonium }+ \text { indaziflam } \\
\text { (Tank mix) }\end{array}$ & $0.5+0.05$ & 1 & 1 & 1 & 1 & 1 & & 1 \\
\hline
\end{tabular}

\section{APPENDIX I}

Scale of evaluation of herbicide treatments' effectiveness according to the European Weeds Research Council (EWRC)

\begin{tabular}{llll}
\hline Note & Coverage rate (\%) & Effectiveness rate (\%) & Interpretation \\
\hline 1 & 99 & 1 & No effectiveness \\
2 & 93 & 7 & Very low effectiveness \\
3 & 85 & 15 & Little marked effectiveness \\
4 & 70 & 30 & Poor effectiveness \\
5 & 50 & 50 & Weediness50\% decrease \\
6 & 30 & 70 & Moderate effectiveness \\
7 & 15 & 85 & Acceptable effectiveness \\
8 & 7 & 93 & Good effectiveness \\
9 & 0 & 100 & Perfect effectiveness \\
\hline
\end{tabular}

Source: Adapted from Mathieu \& Marnotte, (2000)

\section{APPENDIX II}

European Weeds Research Society-scale for visual rating of herbicide toxicity

\begin{tabular}{ll}
\hline Class & \multicolumn{1}{c}{ Symptoms of damage } \\
\hline 1 & No damage/healthy plant \\
2 & Very slight symptoms, weak suppression \\
3 & Slight but clearly visible symptoms \\
4 & Severe symptoms(e.gchlorosis) which do not lead to a negative effect on yield \\
5 & Thinning, severe chlorosis or suppression; yield reduction expected \\
6 & Severe damage up to complete destruction \\
7 & Severe damage up to complete destruction \\
8 & Severe damage up to complete destruction \\
9 & Severe damage up to complete destruction \\
\hline
\end{tabular}

Source: Adapted from Ekhator et al. (2018) 